Uniwersytet Śląski w Katowicach Przegląd Prawa Konstytucyjnego -ISSN 2082-1212--------

DOI 10.15804/ppk.2017.02.14

$-\mathrm{Nr} 2(36) / 2017$

\title{
Recenzja
}

\section{Grzegorz Wierczyński, Udostępnianie informacji o prawie jako warunek skutecznej dziatalności prawodawczej, ISBN: 978-83-7865-272-4, Wydawnictwo Uniwersytetu Gdańskiego, Gdańsk 2015, ss. 322}

Monografia Grzegorza Wierczyńskiego Udostępnianie informacji o prawie jako warunek skutecznej działalności prawodawczej łączy zagadnienia należące głównie do trzech dziedzin: techniki prawodawczej, ogłaszania prawa oraz udostępniania informacji o prawie wraz $\mathrm{z}$ metodami ich poszukiwania przez zwykłych, nieprofesjonalnych odbiorców. Jak widać, obszar ten jest szerszy niż wskazywałby tytuł. Cała praca ma charakter interdyscyplinarny: łączy założenia, metody i pola badawcze teorii prawa, socjologii prawa, a w mniejszym zakresie dotyczy także prawa konstytucyjnego. Dla konstytucjonalistów książka Grzegorza Wierczyńskiego, mimo skromniejszych nawiązań i odniesień do podstawowych problemów tej gałęzi, może być jednak interesująca i skłania do podjęcia pewnych wątków dość istotnych także w perspektywie prawa konstytucyjnego. Autor wyraźniej odnosi się tylko do konstytucyjnych podstaw prawa do informacji, ale trudno czynić z tego zarzut. Cele i metody omawianej pracy nie ogniskują się wokół prawa konstytucyjnego.

Trzeba przyznać, że rzadko zdarza się, by sam tytuł książki był szczególnie frapujący. W tym wypadku jest on nieco zaskakujący, zdaje się nawet podważać ugruntowaną tradycję rozumienia skuteczności regulacyjnej prawa, dla której dostęp do zrozumiałego prawa nie był sprawą najistotniejszą. Jeśli jednak mówić o „informacji o prawie”, to trzeba zakładać przynajmniej 
pewne kwantum jego rozumienia, i to nie tylko przez prawników; to zaś wymaga dostępu nie tylko do ogłaszanych tekstów aktów normatywnych ${ }^{1}$, ale także do odpowiednio przygotowanej informacji o prawie, o jego stosowaniu itd. Wydaje się, że konstytucjonaliści w swoich analizach nie kładą dostatecznego nacisku na obowiązek państwa stworzenia odpowiednich ram dla udostępniania prawa i edukacji prawniczej. Nie jest to najważniejszy warunek urzeczywistniania zasady zaufania do państwa i stanowionego przez nie prawa, ale można mniemać, że nastąpi kiedyś sprzężenie zwrotne między rosnącą kulturą prawną społeczeństwa a jakością stanowionego prawa.

Praca Grzegorza Wierczyńskiego składa się z pięciu rozdziałów. Pierwszy dość zwięźle przedstawia założenia badawcze, cel i hipotezy oraz aktualny stan badań. Zawarte są tu także ustalenia terminologiczne. Pewne zastrzeżenia budzą hipotezy, które z pewnością mają rzetelne podstawy, ale raczej nie zawierają elementu nowości. Zbyt oczywista jest hipoteza, że „techniki włączania norm prawnych do systemu prawa powinny być zestandaryzowane” (s. 13) jak i ta o zmianie metod zdobywania wiedzy o prawie w ostatnich latach (s. 14). Jednakże ustalenia potwierdzające te hipotezy wydają się rzetelne i dociekliwe. Może zabrakło w tej części objaśnienia, w czym Autor upatruje wpływ dostępu do prawa na jego skuteczność. Założenie, że taki związek istnieje nie jest sporne, ale możnaby tu wskazać jakie aspekty skuteczności prawa są w tej perspektywie najważniejsze, czy wystarczy tylko osiągnięcie założonego stanu rzeczy. Pytanie zresztą, czym jest osiągnięcie założonego skutku przez prawodawcę. Brakuje w tej kwestii doprecyzowania. Oczywiście lektura całej pracy nie pozostawia wątpliwości, że chodzi tu o prawo znane, zrozumiałe i żywe w świadomości społecznej. Obiecująca jest zapowiedź badań empirycznych o źródłach pozyskiwania informacji o prawie, tym bardziej, że poprzednio ogłaszane w literaturze prawniczej wyniki w tej sferze nie uwzględniały jeszcze źródeł internetowych, o których będzie mowa poniżej.

W drugim rozdziale czytelnik znajdzie materiał poświęcony uznanym co najmniej od czasów J. Benthama metodom służącym spoistości i czytelności systemu prawa. Doniosłości takich działań jak ustalenie zakresu normowania, tworzenie w miarę możliwości ustaw kompleksowych czy wreszcie

1 Zob. A. Preisner, Podstawy prawne i praktyka ogłaszania aktów normatywnych, [w:] Konstytucyjny system źródet prawa $w$ praktyce, red. A. Szmyt, Warszawa 2005, s. 158 i przywołana tam praca S. Wronkowskiej. 
kodyfikacja nie trzeba objaśniać, choć wciąż rzeczywistość odbiega od założonych modeli - by wspomnieć tylko o chaotycznych zmianach kodeksów. Ta część pracy, choć krótka, jest bardzo gęsta treściowo i pouczająca, zwłaszcza, gdy idzie o dobrze wykorzystany materiał porównawczy i wątki historyczne. Interesujące, choć może kontrowersyjne, są rozwiązania francuskie w zakresie tworzenia kodeksów. Istnieje tam jedna komisja kodyfikacyjna, obejmująca potencjalnie całe prawo tworzone we Francji.

Rozdział trzeci omawianej monografii jest zdecydowanie najobszerniejszy i zajmuje niemal połowę objętości książki. Stanowi on podsumowanie stanu badań polskiej teorii prawa (z istotnymi nawiązaniami do myśli francuskiej i niemieckiej) nad techniką prawodawczą. Autor wychodzi z trafnego założenia, że dobrze zastosowana technika prawotwórcza zwiększa prawdopodobieństwo zrozumienia woli prawodawcy i jej respektowania. Rodzi się jednak wątpliwość, czy nie za dużo miejsca poświęcono analizie tak wielu szczegółowych dyrektyw i postulatów techniki prawodawczej. Nasuwa się uwaga, że pewne partie materiału można by poddać, by użyć wyrażenia Ryszarda Małajnego, kuracji odchudzającej. Mam na myśli rozważania poświęcone niektórym zupełnie niespornym i dobrze opisanym w komentarzach do Zasad techniki prawodawczej zagadnieniom dotyczącym techniki redagowania kolejno występujących w typowym akcie prawnym przepisów. Zaoszczędzone miejsce można byłoby przeznaczyć na analizę roli uzasadnień projektów ustaw oraz materiałów przygotowawczych aktu prawnego, ze szczególnym uwzględnieniem historii powstawania ustaw, dla ich wykładni i powszechnego rozumienia. „Historia legislacyjna” jest bowiem istotnym argumentem, zwłaszcza wobec możliwych kontrowersji co do porządku (kolejności) stosowania dyrektyw wykładni. Trudno powiedzieć, czym kierował się Autor pomijając ten potencjalnie istotny element kształtowania właściwej interpretacji i stosowania prawa. Wprawdzie w obecnej praktyce znaczenie uzasadnienia projektu - zwłaszcza, gdy ten zmienił się w stosunku do tego, co wyrażono w uzasadnieniu - nie jest zbyt duże. Wydaje się jednak, że takie uzasadnienia mogłyby odegrać istotniejszą rolę, podobnie jak inne materiały tzw. historii legislacyjnej².

2 Przystępnie wyrażone przez sąd odwołania do genezy aktu prawnego w rozwiązywaniu sporów o prawo mogą służyć edukacji prawniczej. Oczywiście nie zawsze da się z materiału prac legislacyjnych zrekonstruować najważniejsze cele regulacji. Por. A. Bielska-Brodziak, 
W prawie konstytucyjnym nośnym zagadnieniem jest znaczenie normatywne preambuł do konstytucji. G. Wierczyński do wstępów ustaw zasadniczych się nie odnosi, lecz jego uwagi o pożytkach, ale i zagrożeniach, jakie niosą preambuły, mają przydatność uniwersalną (s. 122-126). Całkowicie trafne i dobrze udokumentowane są uwagi i wnioski dotyczące dyrektyw językowych co do tworzonego prawa. Godny namysłu jest postulat współpracy prawników i językoznawców w fazie redagowania przepisów. Taka współpraca istnieje w pewnym zakresie w RFN czy we Francji (s. 92-93). Racjonalne wydaje się też stanowisko w kwestii względnego charakteru zakazu powtórzeń (por. uwagi w kwestii powtórzenia obowiązku ogłoszenia prawa $\mathrm{z}$ art. 88 ust. 1 Konstytucji w art. 2 ust. 1 ustawy o ogłaszaniu aktów normatywnych i niektórych innych aktów prawnych). W tym przypadku nie jest to zbędna redundancja. Mimo zastrzeżeń poczynionych wyżej, rozdział ten jest interesujący, otwiera pole do refleksji i pewnych wniosków pod adresem prawodawcy. Za szczególnie wartościowy uważam wnikliwie przedstawiony i dobrze wpleciony w tok narracji materiał porównawczy dotyczący techniki prawodawczej, zwłaszcza w Niemczech, we Francji i Włoszech oraz literaturę obcojęzyczną. Ma on głównie znaczenie informacyjne, ale specjaliści z zakresu legislacji mogą zapewne znaleźć w nim rozwiązania inspirujące i możliwe do zastosowania także na polskim gruncie

Rozdział czwarty poświęcony jest formom udostępniania informacji prawnej, na które prawodawca ma największy wpływ. Chodzi mianowicie o ogłaszanie aktów normatywnych (z czym wiąże się domniemanie ich autentyczności), ogłaszanie tekstów jednolitych, tworzenie skorowidzów aktów normatywnych, udostępnianie prawa za pośrednictwem publicznych (niekomercyjnych) systemów informacji. Warto wspomnieć, że w Polsce zasada urzędowego ogłaszania aktów prawnych datuje się od 1505 r., kiedy to przyjęto ją w konstytucji Sejmu Walnego w Radomiu (szerzej zob. recenzowana praca, s. 200). Grzegorz Wierczyński kładzie duży nacisk, i słusznie, na funkcjonalność wyszukiwania informacji w internetowych systemach informacji. Monografia ukończona w 2015 r. nie mogła dotyczyć problemów wynikłych później. Trwający w 2016 r. kryzys publikacyjny wokół wyroków Trybunału

Historia legislacyjna $w$ interpretacji. Kilka impresji na gruncie polskiej praktyki stosowania prawa, [w:] Legislacja czasu przemian przemiany w legislacji. Księga jubileuszowa na XX-lecie Polskiego Towarzystwa Legislacji, red. A. Witorska, M. Lachowski, Warszawa 2016, s. 156 i n. 
Konstytucyjnego, godzący wprost w dyspozycje art. 190 ust. 2 Konstytucji, nie mógł być przez Autora dostrzeżony, a szkoda, bo jest to wysoce niepożądany stan z punktu widzenia dostępu do wiedzy o prawie. W Internetowym Systemie Aktów Prawnych opracowywanym w Kancelarii Sejmu wyroki z okresu wspomnianego kryzysu są pomijane milczeniem.

Dla konstytucjonalistów w czwartym rozdziale książki szczególnie interesujące wydają się rozważania na temat domniemania autentyczności urzędowo ogłaszanych aktów normatywnych (pkt 2.2) i prostowania błędów w urzędowo ogłaszanych tekstach aktów normatywnych (pkt 2.3) ze zwięzłym omówieniem rodzajów tych błędów i chwili ich powstawania (s. 209). Pewnym brakiem wydaje się pominięcie pomocy prawnej płynącej ze strony organów prowadzących postępowanie w sprawach administracyjnych (art. 9 k.p.a i art. 121 Ordynacji podatkowej) czy sądowych (zwłaszcza art. 16 par. 2 zd. pierwsze k.p.k,). Prawdopodobnie Autor uznał, że nie są to mechanizmy ogólnego dostępu do prawa, jednakże w zakończeniu wspomniano o tych formach, co wydaje się pewną niekonsekwencją.

Ostatni rozdział recenzowanej książki jest rzadko spotykanym w literaturze prawniczej przykładem zastosowania metody empirycznej. Prezentowane w nim badania socjologiczne, przeprowadzone na reprezentatywnej próbie 1000 respondentów w 2013 r., dotyczyły następujących źródeł pozyskiwania informacji o prawie: dzienniki urzędowe, internetowe systemy informacji prawnej, prasa, radio i telewizja, nieprofesjonalne serwisy internetowe, edukacja, pracownicy urzędów i sądów, eksperci (w tym adwokaci i radcy prawni) oraz kontakty towarzyskie. Jak już ustalił wielokrotnie przywoływany w pracy Franciszek Studnicki, wobec niemożliwości poznania prawa w całości przeciętny obywatel dociera do prawa ad hoc. Od tego, $\mathrm{w}$ jaki sposób zdobywa się wiedzę o interesujących regulacjach, zależy jej wiarygodność, choć żadnego z wspomnianych źródeł nie można odrzucić całkowicie. Przeprowadzenie tych badań było ze wszech miar uzasadnione, upłynęło już bowiem dużo czasu od poprzednich zakrojonych na szeroką skalę ustaleń M. Boruckiej-Arctowej i F. Studnickiego.

Kilka danych rzeczywiście zastanawia. Tytułem przykładu odnotujmy wybrane z nich. Nie dziwi, że dzienniki urzędowe nie stanowią głównego źródła wiedzy prawnej. Jedynie 10\% badanych korzystało w ciągu 3 lat z tego sposobu dotarcia do prawa (mniej jeszcze, bo 6\%, szukało pomocy prawni- 
ków działających na rynku). Wyraźnie więcej, 21\% objętych badaniem, skorzystało z pomocy pracowników urzędów i sądów. Spory odsetek badanych (25\%) czerpał wiedzę z internetowych systemy informacji prawnej, a jeszcze więcej (34\%) z kręgu towarzyskiego. Respondentów pytano też o dostępność różnych źródeł informacji; jasne jest, że najwięcej osób wskazało na kontakty towarzyskie. Zwraca uwagę, że tylko $6 \%$ osób wskazało bezpłatną pomoc prawną, co może wynikać z braku świadomości jej istnienia.

Trafne jest stanowisko Autora, że dzisiaj dostęp do wiedzy prawnej w dużym stopniu zależy od metody działania profesjonalnych internetowych serwisów informacji prawnej. Grzegorz Wierczyński jest znanym specjalistą $\mathrm{w}$ dziedzinie informatyki prawniczej a jego ustalenia odnoszące się do internetowych systemów informacji prawnej są dobrze poparte tą wiedzą. Można by jednak, jak sądzę, nieco szerzej przedstawić wpływ nowych technologii na odbiór komunikatów prawodawcy. Ciekawe, czy poznawanie prawa za pomocą komputera służy, czy też nie służy gruntownemu poznaniu tego, co ważne i dobremu zapamiętywaniu. Być może wymagałoby to zastosowania narzędzi poznawczych niebędących w dyspozycji Autora. Pewien niedosyt pozostawia kwestia niewątpliwie zaznaczona, ale raczej niedopowiedziana, a mianowicie, jakimi metodami prawodawca powinien wpłynąć na skuteczność przepływu informacji o prawie. Autor zdaje się największą uwagę przywiązywać do prawidłowej techniki redagowania prawa, ale to jest warunek konieczny, lecz niewystarczający.

Zakończenie obok dość typowej syntezy wyników badań zawiera kilka postulatów, na które warto zwrócić uwagę. Grzegorz Wierczyński postuluje położenie większego nacisku na propedeutykę wiedzy o prawie w edukacji szkolnej oraz w mediach elektronicznych i prasie, na doskonalenie zawodowe adwokatów i radców prawnych. Postulaty te z pewnością uzasadnione można byłoby nieco doprecyzować. Jeśli chodzi o tworzenie prawa, to cenna jest propozycja korzystania z wyników badań językoznawstwa, socjologii i psychologii poznawczej.

Wspomniane uchybienia nie przekreślają ogólnie pozytywnej oceny książki. Zwraca uwagę erudycyjny charakter rozważań i doniosłość społeczna podjętych zagadnień. Pożyteczne są też informacje płynące z badań socjologicznych. Badacze prawa konstytucyjnego mogą zaś podjąć pewne wątki $\mathrm{w}$ pracy niewyrażone, ale nasuwające się $\mathrm{w}$ trakcie lektury. Upodmiotowie- 
nie adresata prawa polegające na świadomości swoich praw i obowiązków może być rozpatrywane, co tylko tu sygnalizuję, w świetle zasady państwa prawnego wraz z tym, co z niej wynika: wymogiem ogłoszenia prawa oraz zasadą zaufania do państwa i stanowionego prawa. Istotny jest też aspekt praw informacyjnych jednostki (art. 54 w zw. z art. 61 Konstytucji). Rozumienie przez jednostkę swojej sytuacji prawnej, przynajmniej w najważniejszych dla niej sferach życia wiązać się da z ochroną godności człowieka. To już jednak bardziej dyskusyjne,

Recenzowana książka nie ma wąsko określonej grupy odbiorców. Z pewnością treści prezentowane w tym opracowaniu, w tym przeprowadzone badania socjologiczne, powinny spotkać się z uwagą legislatorów zatrudnionych w różnych ogniwach władzy wykonawczej i ustawodawczej. Można ją jednak polecić wszystkim prawnikom, którym bliska jest sprawa rozhermetyzowania prawa i rozszerzenia dostępu do wiarygodnych komunikatów o prawie. Kultura prawna napotyka dzisiaj na nowe wyzwania i warto czynić, wszystko co możliwe dla jej propagowania. Praca napisana jest dobrym, bogatym i zrozumiałym językiem bez straty dla precyzji rozważań.

Michał Bartoszewicz Politechnika Opolska 